\title{
URGENSI KETERBUKAAN INFORMASI \\ DALAM PENYELENGGARAAN PELAYANAN PUBLIK \\ (Urgency ofDisclosure of Informationin the Implementation ofPublic Service)
}

\author{
Eko Noer Kristiyanto \\ Badan Penelitian dan Pengembangan Hukum dan HAMKementerian Hukum dan HAM RI \\ Jalan H.R Rasuna Said Kav. 4-5 Kuningan Jakarta Selatan 12920 \\ Email: tigers_nova@yahoo.com \\ Tulisan Diterima, 16-2-2016, Revisi 8 Juni 2016, Disetujui diterbitkan 21-6-2016
}

\begin{abstract}
Since 2008, Indonesia has started a new momentum in the era of openness, related to the passing of Law No. 14 of 2008 on Public Information (KIP). Disclosure of public information is very important because people can control every step and measures taken by the government, especially the Public Agency. Operation of power in a democratic country should at all times be accountable back to the community. Accountability brings to the good governance that leads to the guarantee of human rights (HAM). Public disclosure is an important part of public service is also a right that is very important and strategic for citizens to get access to other rights, because of how it might be to get the rights and other services properly obtained information regarding such rights it is not obtained appropriately and correctly. The poor performance of public services for, among others, have not been implemented because of transparency and participation in public service delivery. This paper attempts to explain the correlation and importance of the right to information of the public service.
\end{abstract}

Keywords: Public Service, Transparency, Participation, Accountabilitys

\begin{abstract}
ABSTRAK
Sejak Tahun 2008, Indonesia telah memulai sebuah momentum baru dalam era keterbukaan, terkait dengan disahkannya Undang-Undang Nomor 14 Tahun 2008 Tentang Keterbukaan Informasi Publik(KIP). Keterbukaan informasi publik sangat penting oleh karena masyarakat dapat mengontrol setiap langkah dan kebijakan yang diambil oleh Badan Publik terutama pemerintah. Penyelenggaraan kekuasaan dalam negara demokrasi harus setiap saat dapat dipertanggungjawabkan kembali kepada masyarakat. Akuntabilitas membawa ke tata pemerintahan yang baik yang bermuara pada jaminan hak asasi manusia (HAM). Keterbukaan informasi publik merupakan bagian penting dari penyelenggaraan pelayanan publik juga merupakan hak yang sangat penting dan strategis bagi warga negara untuk menuju akses terhadap hak-hak lainnya, karena bagaimana mungkin akan mendapatkan hak dan pelayanan lainnya dengan baik jika informasi yang diperoleh mengenai hak-hak tersebut tidaklah didapatkan secara tepat dan benar.Buruknya kinerja pelayanan publik selama ini antara lain dikarenakan belum dilaksanakannya transparansi dan partisipasi dalam penyelenggaraan pelayanan publik. Tulisan ini mencoba menjelaskan korelasi dan pentingnya hak atas informasi terhadap penyelenggaraan pelayanan publik.
\end{abstract}

Kata Kunci: Pelayanan Publik, Transparansi, Partisipasi, Akuntabilitas

\section{PENDAHULUAN}

Konsep desentralisasi dianggap sebagai solusi yang mampu mewujudkan kesejahteraan masyarakat didaerah. Secara konseptual,kebijakan desentralisasi dan otonomi daerah dilaksanakan melalui pemberian kewenangan kepada daerah untuk mengatur dan mengurus sendiri urusan pemerintahan, kecuali urusan pemerintahan yang oleh undang-undang ditetapkan sebagai urusan Pemerintah Pusat. Namun, setelah lebih dari satu dekade terjadi pelencengan makna desentralisasi menjadi otonomi bagi elite dan pejabat. Kondisi ini dapat dilihat dari minimnya pelibatan masyarakat dalam setiap pengambilan kebijakan publik. Masih ada pemerintah daerah (pemda) yang belum menerapkan prinsipprinsip transparansi terutama dalam proses dan mekanisme penyusunan dan pengesahan berbagai kebijakan publik misalnya peraturan daerah 
(perda), peraturan kepala daerah, atau keputusan kepala daerah. Bahkan ada kepala daerah yang tidak melaporkan Informasi Penyelenggaraan Pemerintah Daerah (IPPD)-nya kepada masyarakat (http://www.ditjen-otda.depdagri. go.id/index.php/categoryblog/70-maknadesentralisasi-itu-pelibatan-masyarakat). Kondisi ini menyebabkan masyarakat tak memiliki ruang untuk memberikan saran, masukan, dan kritikannya terhadap setiap kebijakan publik yang dirancang pemerintah daerah.

Minimnya partisipasi masyarakat ini, bukan karena masyarakat tidak peduli, tetapi karena mereka sulit mengakses informasi terkait agenda pemda (perda, peraturan dan keputusan kepala daerah, rencana pembangunan daerah, rancangan dan pembahasan kebijakan daerah, laporan penyelenggaraan pemda, dan informasi publik lainnya). (Puslitbang BPHN, 2013).Transparansi inilah yang belum diterapkan semua pemerintah daerah, data penelitian BPHN menunjukkan bahwa dari 33 provinsi di Indonesia, baru 20 provinsi saja yang membentuk komisi informasi . Padahal salah satu aktualisasi nilai dan prinsip-prinsip good governance adalah transparansi(http:// agusdarwis.wordpress.com/2010/08/09/ pelayanan-publik-keterbukaan-informasi/). Melalui transparansi diharapkan terjalin komunikasi, sehingga kepala daerah mendapat saran, dan kritikan yang membangun, tidak mengandalkan masukan dari birokrasi semata atau dari dewan (DPRD) yang sangat politis, sehingga akan terjadi kesesuaian antara apa yang disediakan oleh pemerintah dengan apa yang dibutuhkan masyarakat. Pelayanan publik yang tidak dibarengi dengan keterbukaan informasi publik justru akan menjauhkan harapan masyarakat terhadap kualitas pelayanan itu sendiri dan justru akan dapat menimbulkan penyalahgunaan kewenangan dari pejabat negara yang seharusnya memberikan pelayanan kepada publik.

Hak atas Informasi menjadi penting karena dengan terbukanya penyelenggaraan negara untuk diawasi publik, penyelenggaraan negara tersebut semakin dapat dipertanggungjawabkan. Hak setiap orang untuk memperoleh informasi juga relevan untuk meningkatkan kualitas pelayanan dan juga pelibatan masyarakat dalam proses pengambilan keputusan publik. Partisipasi atau pelibatan asyarakat tidak banyak berarti tanpa jaminan keterbukaan Informasi Publik(http://agusdarwis. wordpress.com/2010/08/09/pelayanan-publikketerbukaan-informasi/). Dengan membuka akses publik terhadap informasi diharapkan badan publik termotivasi untuk bertanggung jawab dan berorientasi kepada pelayanan publik yang sebaik-baiknya. Dengan demikian, hal itu dapat mempercepat perwujudan pemerintahan yang terbuka yang merupakan upaya strategis mencegah praktik korupsi, kolusi, dan nepotisme $(\mathrm{KKN})$, dan terciptanya kepemerintahan yang baik (good governance). Melalui pelaksanaan prinsip keterbukaan, akan tercipta pelayanan badan publik yang prima dan peran serta masyarakatyang transparan dan akuntabilitas yang tinggi sebagai salah satu prasyarat untuk mewujudkan demokrasi yang hakiki.

Sejak Tahun 2008, Indonesia telah memulai sebuah momentum baru dalam era keterbukaan, terkait disahkannya Undang-Undang Nomor 14 Tahun 2008 Tentang Keterbukaan Informasi Publik (KIP).Keterbukaaninformasipubliksangatpenting oleh karena masyarakat dapat mengontrol setiap langkah dan kebijakan yang diambil oleh Badan Publik terutama pemerintah. Penyelenggaraan kekuasaan dalam negara demokrasi harus setiap saat dapat dipertanggungjawabkan kembali kepada masyarakat. Akuntabilitas membawa ke tata pemerintahan yang baik yang bermuara pada jaminan hak asasi manusia (HAM).

Deklarasi Universal Hak Asasi Manusia PBB Bab 19 mengatur tentang hak manusia yang paling dasar menyatakan bahwa:

"Setiap orang mempunyai hak atas kebebasan mengemukakan pendapat dan gagasan; hak ini mencakup hak untuk memegang pendapat tanpa campur tangan, dan mencari, menerima dan menyebarkan informasi dan gagasan melalui media apapun tanpa mempertimbangkan garis batas negara."

Selain itu, salah satu bagian dari substansi HAM yang telah diakui oleh PBB sebagai bagian dari HAM sejak generasi pertama adalah Hak atas kebebasan memperoleh informasi. PBB sejak tahun 1946 telah mengadopsi Resolusi 59 ayat (1) yang menyebutkan bahwa:

"Kebebasan informasi adalah hak asasi yang fundamental dan merupakan tanda dari seluruh kebebasan yang akan menjadi titik perhatian PBB"Dalam sebuah laporan di PBB pun dinyatakan bahwa: 


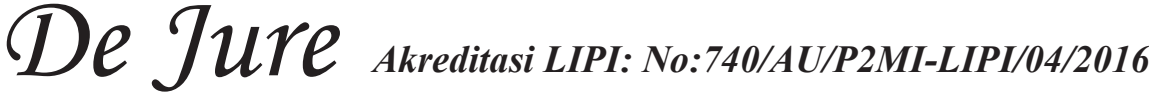

"Kebebasan informasi merupakan salah satu HAM yang sangat penting, sebab kebebasan tidak akan efektif apabila seseorang tidak memiliki akses terhadap informasi. Akses informasi merupakan dasar bagi kehidupan demokrasi, oleh karenanya tendensi untuk menyimpan informasi dari masyarakat haruslah diperhatikan".

Hal ini selaras dengan Pasal 28 F UndangUndang Dasar Negara Republik Indonesia Tahun 1945 (UUD 1945) menyatakan bahwa:

"Setiap orang berhak untuk berkomunikasi dan memperoleh Informasi untuk mengembangkan pribadi dan lingkungan sosialnya, serta berhak untuk mencari, memperoleh, memiliki, dan menyimpan Informasi dengan menggunakan segala jenis saluran yang tersedia."

Berkaitan dengan hal ini maka untuk memberikan jaminan terhadap semua orang dalam memperoleh Informasi, dibentuk undang-undang yang mengatur tentang Keterbukaan Informasi Publik. Informasi publik adalah Informasi publik adalah informasi yang dihasilkan, disimpan, dikelola dan/atau dikirim/diterima oleh suatubadan publik yang berkaitan dengan penyelenggara dan penyelenggaraan negara dan/atau penyelenggara dan penyelenggaraan badan publik lainnya yang sesuai dengan undang-undang ini serta informasi lain yang berkaitan dengan kepentingan publik.

Keterbukaan informasi ini penting oleh karena: pertama, informasi merupakan kebutuhan pokok setiap orang bagi pengembangan pribadi dan lingkungan, sosialnya serta merupakan bagian penting bagi ketahanan nasional; kedua, hak memperoleh informasi merupakan hak asasi manusia dan keterbukaan informasi publik merupakan salah satu ciri penting negara demokratis yang menjunjung tinggi kedaulatan rakyat untuk mewujudkan penyelenggaraan negara yang baik; ketiga, keterbukaan informasi publik merupakan sarana dalam mengoptimalkan pengawasan publik terhadap penyelenggaraan negara dan Badan Publik lainnya dan segala sesuatu yang berakibat pada kepentingan publik; keempat, pengelolaan informasi publik merupakan salah satu upaya untuk mengembangkan masyarakat informasi
Untuk itulah UU No. 14 Tahun 2008 tentang Keterbukaan Informasi Publik mengamanatkan dibentuknya Komisi Informasi, termasuk Komisi Informasi di Daerah. Hal tersebut sejalan dengan amanah UU No. 14 Tahun 2008 tentang Keterbukaan Informasi Publik dan dalam rangka memberikan pelayanan yang optimal kepada masyarakat.

Provinsi Jawa Barat sudah membentuk Komisi Informasi Provinsi Jawa Barat pada tanggal 29 April 2011 melalui Keputusan Gubernur Provinsi Jawa Barat Nomor 821.2/ Kep.566-Diskominfo/2011 tentang Pengangkatan Komisoner pada Komisi Informasi Provinsi Jawa Barat tertanggal 19 April 2011 dengan jumlah komisioner 5 orang. Sengketa informasi yang masuk ke Komisi Informasi Jawa Barat terus meningkat sejak tahun pembentukannya hingga akhirnya Komisi Informasi Jawa Barat menangani sengketa informasi publik sebanyak lebih dari 600 sengketa. Namun seiring waktu tampaknya euforia terkait keterbukaan informasi semakin surut bahkan pemerintah dan masyarakat terkesan tidak menganggap penting tentang hak yang secara filosofis dan implementatif sesungguhnya sangat penting ini, hal ini terjadi bukan hanya terjadi di Jawa Barat namun juga hampir di seluruh Indonesia. Sebagai contoh adalah belum seluruh provinsi di Indonesia membentuk Komisi Informasi Provinsi, padahal ini adalah amanat Undang-Undang, contoh lainnya adalah beberapa hasil penelitian yang menunjukkan bahwa tinggirendahnya angka pengaduan sebenarnya tidak memiliki korelasi terkait kesadaran masyarakat terhadap informasi, karena bisa saja angka pengaduan tinggi justru pertanda buruk karena berarti badan publik masih tidak melaksanakan UU KIP dengan baik, atau bisa juga sebaliknya, bahwa kesadaran masyarakat sudah baik sehingga mereka berinisiatif untuk mengadukan badan publik ke Komisi Informasi, namun demikian beberapa penelitian menemukan fakta bahwa pengaduan didominasi segelintir orang, dalam artian satu pihak dapat mengadukan beberapa badan publik secara sekaligus, bahkan penelitian tim puslitbang BPHN-Kemenkumham RI menemukan kenyataan bahwa UU KIP dijadikan alat untuk melakukan pemerasan oleh oknumoknum tertentu.

Begitupun sebaliknya, angka pengaduan yang rendah dapat berarti badan publik sudah 
membuka informasinya dengan baik atau justru kesadaran masyarakat rendah dan sosialisasi yang buruk terkait hak informasi di daerah tersebut sehingga masyarakat tak paham bagaimana mekanisme untuk mengadukan badan publik terkait keterbukaan informasi. Khusus di Jawa Barat, berbagai seremoni dan penghargaan yang bersifat formil menempatkan provinsi Jawa Barat termasuk provinsi yang cukup baik dalam pengimplementasian Undang-Undang Keterbukaan Informasi Publik, Provinsi Jawa Barat menduduki peringkat pertama dalam mengimplementasikan peraturan perundangundangan KIP. Hal iniditandai dengan jumlah perkara yang diselesaikan, kegiatan Monitoring dan Evaluasi terhadap Badan Publik Kabupaten/ Kota di Jawa Barat, adanya Kelembagaan dan Kerjasama, adanya kegiatan edukasi, sosialisasi, dan advokasi, adanya fasilitas Komisi Informasi Provinsi Jawa Barat yang lebih representatif untuk menyelesaikan perkara informasi publik.

Namun apakah keadaan yang dianggap sudah baik ini berkorelasi positif dengan pelayanan publik secara umum di Jawa Barat? Karena ternyata banyak pemberitaan dan penelitian menunjukkan bahwa pelayanan dasar di Jawa Barat masih perlu ditingkatkan, walau pelayanan publik tak semata dilakukan oleh badan publik pemerintah semata namun pelayanan yang dilakukan oleh pemerintah mendapat sorotan utama, karena dalam konteks penyelenggaraan pelayanan publik, negara adalah pihak pertama dan utama yang bertanggungjawab dalam upaya pemenuhan hak-hak rakyat, bukan yang lainnya. Demikian pula pada proses reformasi dalam sektor pelayanan publik, negaralah yang harus mengambil peran dominan (Puspitosari, 2011). Dan di era otonomi daerah ini maka pemerintah daerah adalah pengemban utama tugas pelayanan di daerah. Temuan Direktorat Jenderal Otonomi Daerah menyatakan bahwa masih banyak organisasi pemerintah daerah yang tidak menerapkan standar pelayanan dalam melaksanakan tugasnya Selain itu Standar Operational Procedure (SOP) seringkali tidak diinformasikan kepada masyarakat luas. Hal tersebut dikemukakan oleh Dan Satriana yang mengatakan bahwa masih banyak badan-badan publik yang tidak menginformasikan mengenai standar pelayanan yang mengenai pelayanan publik yang mereka lakukan, terutama terkait standar teknis SOP.
Alasan lainnya adalah bahwa badan publik pemerintah lebih banyak diadukan dalam hal pelaksanaan UU KIP hingga saat ini (keterangan Dan Satriana, komisioner Komisi Informasi Provinsi Jawa Barat).

Lalu bagaimana sebenarnya korelasi antara Keterbukaan Informasi Publik dengan Pelayanan Publik dalam konteks Implementasi Undang-Undang Nomor 14 Tahun 2008 Tentang Keterbukaan Informasi Publik Dalam Penyelenggaraan Pelayanan Publik Oleh Pemerintah Daerah?

\section{METODE}

Metode penelitian yang digunakan dalam penulisan ini adalah metode penelitian hukum normatif-sosiologis, metode penelitian hukum normatif pada dasarnya meneliti kaidahkaidah hukum dan asas-asas hukum, menelaah permasalahan dengan berpedoman pada data sekunder yaitu: bahan hukum primer, sekunder dan tersier.Bahan hukum primer yang dimaksud adalah Undang-Undang Dasar 1945, undangundang, peraturan pemerintah, dan peraturan perundang-undangan lain yang berkaitan dengan judul penelitian.Bahan hukum sekunder yang dimaksud adalah doktrin, ajaran para ahli, hasil karya ilmiah para ahli, berita-berita dan hasil wawancara pihak terkait seperti ketua Komisi Informasi yang diperoleh secara langsung maupun dari surat kabar serta situs-situs internet yang relevan dengan judul penelitian.

Kemudian secara sosiologis, data sekunder tersebut diperkuat oleh data-data empirik yang ditemukan penulis dalam penelitian ke kantor Komisi Informasi.

Data di atas dikumpulkan melalui studi kepustakaan (library research), penelurusan melalui media internet (online research), dalam hal ini penulis menitikberatkan konteks Implementasi Undang-Undang Nomor 14 Tahun 2008 Tentang Keterbukaan Informasi Publik Dalam Penyelenggaraan Pelayanan Publik Oleh Pemerintah Daerah

\section{PEMBAHASAN}

\section{A. Pelayanan Publik}

Pelayanan publik adalah hak konstitusional warga negara. Konstitusi Indonesia mengamanat- 


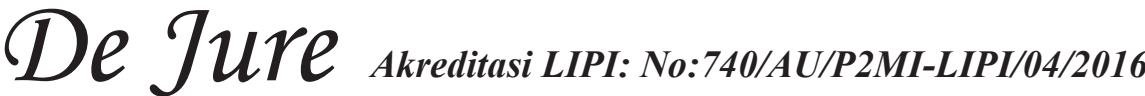

kan negara kesejahteraan, amanat dan konsepsi tersebut terdapat dalam alinea keempat pembukaan UUD 1945 ;

"untuk melindungi segenap bangsa Indonesia dan seluruh tumpah darah Indonesia, dan untuk memajukan kesejahteraan umum, mencerdaskan kehidupan bangsa"

Isi dari pembukaan UUD 1945 diatas menjelaskan bahwa negara memiliki tanggung jawab untuk memajukan kesejahteraan umum dalam arti yang seluas-luasnya karena berkaitan dengan kepentingan masyarakat secara keseluruhan. Dalam hal ini tanggung jawab negara adalah bagaimana mengusahakan semua prasyarat, kondisi dan sarana maupun prasarana yang dapat mendukung tercapainya kesejahteraan umum (Puspitosari, 2011). Kesejahteraan umum adalah suatu kondisi tertentu yang dirasakan oleh publik mengenai kehidupannya yang baik dan berkeadilan. Kondisi publik yang sejahtera dapat dideskripsikan sebagai keadaan masyarakat yang bebas dari perasaan lapar, kemiskinan kecemasan akan hari esok, perasaan takut dari penindasan dan dari ketidakadilan. Dalam batang tubuh UUD 1945, kewajiban negara untuk menyelenggarakan pelayanan publik tercantum dalam Pasal 34 ayat (3) yang menyatakan:

"Negara bertanggung jawab atas penyediaan fasilitas pelayanan kesehatan dan fasilitas pelayanan umum yang layak"

Untuk memenuhi kesejahteraan itulah maka negara melakukan pelayanan kepada masyarakatnya yang kita kenal sebagai pelayanan publik. Pelayanan publik adalah termasuk hak dalam konteks hak ekosob, hak ekosob merupakan bagian yang esensial dalam hukum HAM internasional; bersama-sama dengan hak-hak sipil dan politik menjadi bagian dari the international bill of human rights. Dengan demikian hak ekosob tidak dapat ditempatkan di bawah hak-hak sipil dan politik. Hak ekosob mengubah kebutuhan menjadi hak, atas dasar keadilan dan martabat manusia, hak ekosob memungkinkan masyarakat menjadikan kebutuhan pokok mereka sebagai sebuah hak yang harus diklaim (rights to claim) dan bukannya sumbangan yang didapat (charity to receive). Hak-hak ekosob sering juga disebut sebagai hak-hak positif, karena tidak seperti dalam hak-hak sipil dan politik, dalam hak ekosob ini negara harus berperan atau mengambil langkah positif untuk menjamin terpenuhinya hak-hak ini.
Pelayanan publik menjadi suatu tolok ukur kinerja pemerintah yang paling kasat mata. Dalam hal ini masyarakat dapat langsung menilai kinerja pemerintah berdasarkan kualitas layanan publik yang diterima, karena kualitas layanan publik menjadi kepentingan banyak orang dan dampaknya langsung dirasakan masyarakat dari semua kalangan.

Pelayanan publik adalah segala kegiatan pelayanan yang dilaksanakan oleh penyelenggara pelayanan publik sebagai upaya pemenuhan kebutuhan penerima pelayanan, maupun dalam rangka pelaksanaan ketentuan peraturan perundang-undangan. Masyarakatyangmerupakan pelanggan dari pelayanan publik, juga memiliki kebutuhan dan harapan pada kinerja penyelenggara pelayanan publik yang profesional. Dengan tugas Pemerintah Pusat maupun Pemerintah Daerah adalah bagaimana memberikan pelayanan publik yang mampu memuaskan masyarakat.

Penyelenggara pelayanan publik dalam memberikan pelayanan publik menggunakan standar pelayanan yaitu tolok ukur yang dipergunakan sebagai pedoman penyelenggaraan pelayanan dan acuan penilaian kualitas pelayanan sebagai kewajiban dan janji penyelenggara kepada masyarakat dalam rangka pelayanan yang berkualitas, cepat, mudah, terjangkau dan terukur. Kualitas merupakan janji pelayanan agar masyarakat sebagai pihak yang dilayani merasa puas dan diuntungkan. Ketika masyarakat mempunyai suatu urusan/keperluan pada sebuah badan publik, ia akan merasa senang atau tidak senang saat dilayani oleh petugas. Jika masyarakat merasa senang dilayani oleh petugas tersebut, maka pelayanan petugas itu memuaskan atau pelayanan petugas berkualitas. Sebaliknya, ketika pelanggan merasa dirugikan aparat akibat pelayanan yang berbelit-belit, tidak terbuka/ transparan tentang apa yang diharapkan, maka dapat dikatakan pelayanannya tidak berkualitas (BPHN, 2011).

Adanya implementasi kebijakan desentralisasi dan otonomi daerah di Indonesia yang tertuang dalam Undang-Undang Nomor 23 Tahun 2014 Tentang Pemerintahan Daerah menyebutkan bahwa pemerintah mempunyai tanggung jawab, kewenangan dan menentukan standar pelayanan minimal. Hal ini mengakibatkan setiap Daerah (Kota/Kabupaten) di Indonesia harus melakukan pelayanan publik sebaik-baiknya dengan standar 
minimal (http://digilib.its.ac.id/public/ITSUndergraduate-8118-1303100062-Bab1.pdf).

Menurut Dan Satriana, Komisioner Komisi Informasi Jawa Barat, Informasi mengenai Standar Pelayanan ini pula yang seringkali tidak dipenuhi oleh badan publik, juga terkait Standar Operasional Prosedur yang seringkali tidak diinformasikan kepada masyarakat luas. Masih banyak badan-badan publik yang tidak menginformasikan mengenai standar pelayanan yang mengenai pelayanan publik yang mereka lakukan, terutama terkait standar teknis SOP.

Dalam konteks keterbukaan dan partisipasi masyarakat seperti dikehendaki oleh UndangUndang Keterbukaan Informasi Publik dan Undang-Undang Pelayanan Publik, Undang-Undang Nomor 23 Tahun 2014 Tentang Pemerintahan Daerah pun menghendaki hal serupa, bahwa pemerintah daerah dalam menyelenggarakan pemerintahan daerah haruslah mengacu kepada keterbukaan dan partisipasi masyarakat. Hal ini terlihat pada Pasal 58 huruf d bahwa salah satu asas dalam penyelenggaraan pemerintahan daerah adalah asas keterbukaan. Asas keterbukaan adalah asas yang membuka diri terhadap hak masyarakat untuk memperoleh informasi yang benar, jujur dan tidak diskriminatif tentang penyelenggaraan negara dengan tetap memperhatikan perlindungan atas hak asasi pribadi, golongan dan rahasia negara.

\section{Keterbukaan Informasi}

Hak atas informasi merupakan hak yang sangat penting dan strategis bagi warga negara untuk akses terhadap hak-hak lainnya, karena bagaimana mungkin akan mendapatkan hak pendidikan, kesehatan, pelayanan dan lainlain. dengan baik jika informasi yang diperoleh mengenai hak-hak tersebut tidak didapatkan secara tepat dan benar.

Hak untuk mendapat informasi tidak hanya dijamin dalam kesepakatan Internasional tetapi dijamin juga secara tegas dalam konstitusi negara Republik Indonesia. Pasal 28 F Undang-Undang Dasar Negara Republik Indonesia Tahun 1945 menyatakan bahwa:

"Setiap orang berhak untuk berkomunikasi dan memperoleh informasi untuk mengembangkan pribadi dan lingkungan sosialnya, serta berhak untuk mencari, memperoleh, memiliki, dan menyimpan
Informasi dengan menggunakan segala jenis saluran yang tersedia”.

Dalam hal ini, keberadaan hak asasi manusia sebagai hak konstitusional, termasuk hak atas kebebasan mendapatkan informasi dari perspektif konstitusi.

Wheare menyatakan bahwa keberadaan konstitusi berkembang dari ide pemerintahan yang terbatas atau pahamkonstitusionalisme agar kekuasan tidak disalahgunakan (Budiarjo, 1993). Menjadi perhatian utama dalam paham konstitusionalisme, bahwa walaupun pemerintah (dalam arti luas) dibentuk untuk melayani kepentingan orang banyak, namun diperlukan pembatasan kekuasaan ketika menjalankan kekuasaan.

Konstitusi tidak hanya memuat pembagian kekuasaan dalam bentuk pembentukan lembagalembaga negara dan batas-batas kekuasaannya, tetapi juga menjamin hak asasi manusia.

Dijaminnya hak asasi manusia dalam konstitusi merupakan suatu bentuk transformasi hak asasi manusia dari hak-hak moral menjadi hak-hak hukum (Perwira, 2009). Sebagai hakhak konstitusional. Dalam hal ini, konstitusi tidak menciptakan hak-hak baru, melainkan hanya mengakui keberadaan hak asasi manusia sebagai hak-hak yang melekat pada manusia secara alamiah (Brewer-Car'Ias).

Salah satu bagian dari substansi HAM yang telah diakui oleh PBB sebagai bagian dari HAM sejak generasi pertama adalah Hak atas kebebasan memperoleh informasi. PBB sejak tahun 1946 telah mengadopsi resolusi 59 ayat 1 yang menyebutkan bahwa:

"Kebebasan informasi adalah hak asasi yang fundamental dan merupakan tanda dari seluruh kebebasan yang akan menjadi titik perhatian PBB".

Dalam sebuah laporan di PBB pun dinyatakan bahwa:

"Kebebasan informasi merupakan salah satu HAM yang sangat penting, sebab kebebasan tidak akan efektif apabila seseorang tidak memiliki akses terhadap informasi. Akses informasi merupakan dasar bagi kehidupan demokrasi, oleh karenanya tendensi untuk menyimpan informasi dari masyarakat haruslah diperhatikan". 


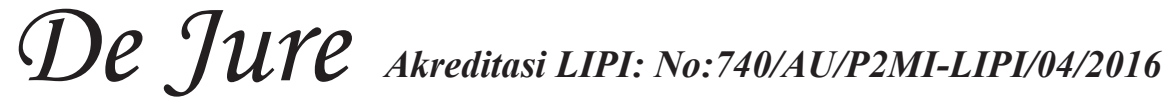

Tanpa adanya partisipasi dan kebebasan memperoleh informasi tidak akan ada interaksi antara warga negara dan pemerintah, yang dapat mengakibatkan terjadinya penyalahgunaan kekuasaan. (Mihradi, 2011) menyatakan bahwa dalam pemerintahan yang terbuka dan transparan maka ada enam hak publik yang harus dijamin, yaitu:

a. Hak publik untuk memantau dan mengamati perilaku pejabat publik (dalam menjalankan fungsi publiknya), (right to observe).

b. Hak publik untuk mendapatkan informasi publik (access to information).

c. Hak publik untuk berpartisipasi dalam pembentukan kebijakan publik (right to participate).

d. Hak publik untuk dilindungi dalam mengungkap fakta dan kebenaran (whistle blower protection).

e. Hak atau kebebasan berekspresi yang diwujudkan melalui kebebasan pers yang berkualitas.

f. Hak publik untuk mengajukan keberatan (right to appeal).

Sementara itu, hak untuk mendapatkan informasi atau jaminan hak atas kebebasan memperoleh informasi publik terdiri atas lima hal, yaitu:

a. Hak untuk mengetahui (right to know).

b. Hak untuk menghadiri pertemuan publik (right to observe/right to attend public meeting).

c. Hak untuk mendapatkan salinan informasi (right to obtain the copy);

d. Hak untuk diinformasikan tanpa harus ada permintaan (right to be informed).

e. Hak untuk menyebarluaskan informasi (right to disseminate).

Kebebasan memperoleh informasi akan menciptakan pemerintahan yang bersih, serta meningkatkan kualitas partisipasi masyarakat dalam perumusan kebijakan publik dan meningkatkankualitaspengawasan publik. Dengan demikian, transparansi dan keterbukaan informasi dapat dipandang sebagai tata pemerintahan yang baik dan akuntabel.
Hak atas informasi juga diatur didalam berbagai dokumen HAM seperti konvensi HAM Eropa yang menekankan bahwa hak untuk mencari, menerima, dan memberikan informasi dan pemikiran dalam hal ini "tidak memandang batas-batas" dan tidak mendapat gangguan dari negara. Pembatasan-pembatasan tertentu tetap dimungkinkan dengan syarat-syarat tertentu. Konvensi HAM eropa, misalnya melarang penyingkapan informasi yang diterima secara rahasia atau untuk pemantauan dan keadilan di pengadilan (Zulkarnain, 2006). Berkaitan dengan hal tersebut, A. Patra M. Zen mengungkapkan, hak untuk informasi selain merupakan bagian dari hak sipil dan politik, namun juga terkait erat dengan pemenuhan hak asasi lainnya, termasuk hak ekonomi, sosial, dan budaya (Zulkarnain, 2006).

Kesepakatan dari Regional Council on Human Rights in Asia menegaskan pula arti penting hak atas informasi yang wajib dijamin pemerintah. Sebab, kebebasan memperoleh informasi merupakan bagian dari hak asasi manusia dan sekaligus merupakan salah satu ciri terpenting dalam negara demokrasi untuk mewujudkan pemerintahan yang terbuka (open government). Kebebasan memperoleh informasi publik merupakan elemen penting mengoptimalkan pengawasan publik terhadap pelaksanaan roda organisasi pemerintahan dan lembaga-lembaga negara lain untuk mendorong pemerintahan yang akuntabel.

Kebebasan dan kemudahan untuk memperoleh informasi adalah sebagai sarana kehidupan berdemokrasi. Untuk itu kebebasan mencari, memperoleh dan menyebarluaskan informasi merupakan hak asasi manusia dan hak konstitusional warga negara yang tidak boleh diabaikan. Hak atas informasi yang merupakan salah satu hak asasi manusia dan menjadi landasan atas pemenuhan hak-hak lain, tidak akanefektif apabila tidak ada keterbukaan dan kemudahan dalam memperoleh informasi yang lebih luas dan tidak terdistorsi, karena keterbukaan informasi merupakan penentuan kadar dan nilai bagi kehidupan demokrasi.

Keterbukaan informasi sekaligus sebagai perangkat bagi masyarakat untuk mengontrol dan mengawasi setiap langkah penyelenggara negara. Dalam sistem demokrasi yang menyatakan kekuasaan berasal dari rakyat, oleh rakyat dan 
untuk rakyat. Maka dengan demikian sudah semestinya rakyat juga berhak mengkritisi dan mengontrol setiap kebijakan yang diambil dan dijalankan oleh pemerintah.

Untuk menyongsong sebuah masyarakat yang demokratis memerlukan dukungan perangkat hukum dan kontrol masyarakat terhadap penyelenggara negara. Salah satu cara memperkuat kontrol masyarakat itu adalah dengan adanya jaminan untuk memperoleh informasi. Dengan adanya transparansi dan keterbukaan informasi, penyalahgunaan kewenangan dan kekuasaan oleh pemerintah dapat dicegah, sehingga pada akhirnya akan tercipta pemerintahan yang bersih, transparan dan akuntabel.

Pemerintahan yang bersifat terbuka pun dapat meminimalkan terjadinya praktik korupsi, hal ini disebabkan, korupsi umumnya tumbuh dan berkembang pada rezim ketertutupan.

Konsep transparansi dan informasi tidak saja berkaitan erat dengan akuntabilitas tetapi juga dengan rule of law pada umumnya. Kedua konsep tersebut dapat dipandang sebagai prasyarat yang diperlukan bagi keberhasilan partisipasi masyarakat umum dalam kehidupan berbangsa dan bernegara.

Pemenuhan hak atas kebebasan memperoleh informasi publik merupakan salah satu indikator dianutnya konsepsi negara hukum sekaligus demokrasi yang bercirikan pengakuan atas hak asasi. Menurut Jimly Asshidiqie, dalam konsep negara hukum yang demokratis (democratische rechtsstaat) atau negara demokrasi berdasar atas hukum, salah satu ciri pokoknya adanya pengakuan dan penghormatan terhadap hak asasi manusia. Ini mengandung makna hak atas kebebasan memperoleh informasi publik mutlak dijamin sebagai bagian dari hak asasi manusia (Asshiddiqie, 2005)..

Inti dalam tata pemerintahan tidak selalu harus berurusan dengan demokrasi, tetapi juga berurusan dengan legitimasi dan akuntabilitas. Dengan demikian, dapat dijadikan argumen bahwa tata pemerintahan yang lebih baik adalah tata pemerintahan yang akuntabel terhadap pernduduknya, semakin akuntabel maka semakin besar kemungkinan pemerintah ini akan menghormati hak sipil dasar (Mattejkaer, 2003).

Hak masyarakat atas informasi tidak dapat disandarkan pada itikad baik pemerintah, tetapi dibutuhkan aturan atau kebijakan yang secara khusus mengatur jaminan hukum atas hak tersebut. Oleh karena itu, langkah pemerintah mengeluarkan Undang-undang Nomor 14 Tahun 2008 Tentang Keterbukaan Informasi Publik merupakan wujud nyata keseriusan pemerintah melibat masyarakat dalam perannya sebagai pengawas dan pengendali pelaksanaan birokrasi, sehingga hak masyarakat akan terpenuhi seutuhnya.

Implikasi penerapan UU KIP terhadap masyarakat atau publik adalah terbukanya akses bagi publik untuk mendapatkan informasi yang berkaitan dengan kepentingan publik, terbukanya akses bagi publik untuk berpartisipasi aktif dalam proses pembuatan kebijakan publik, termasuk didalamnya akses untuk pengambilan keputusan dan mengetahui alasan pengambilan keputusan yang berkaitan dengan kepentingan publik.

Dalam hal badan publik yang terlibat dalam penyelenggaraan pelayanan publik di daerah, penulis memilih fokus kepada pihak pemerintah daerah sebagai objek penelitian meskipun badan publik tidak hanya pemerintah daerah semata, karena pemerintah adalah perwujudan negara untuk melakukan fungsi pelayanan. M Ryaas Rasjid mengatakan bahwa pemerintahan pada hakekatnya adalah pelayanan kepada masyarakat, pemerintahan tidak diadakan untuk melayani dirinya sendiri, akan tetapi untuk melayani masyarakat (Rasyid, 1998).

\section{Keterbukaan Informasi Menunjang Pelayanan Publik Yang Baik}

Dua dari sekian indikator pelayanan publik yang baik adalah dengan adanya keterbukaan dan partisipasi, ini pun sesuai dengan asas pelayanan publik yang tercantum dalam Pasal 4 Undang-Undang Nomor 25 Tahun 2009 Tentang Pelayanan Publik. Korelasi antara keterbukaan dan pelayanan publik cukup menarik dan membuat banyak opini yang mengaitkan dua objek tersebut, dan hubungan keduanya semakin menarik untuk diteliti dan dikaji lebih lanjut pasca terbitnya dua perundang-undangan baru terkait kedua hal tersebut. Dalam konteks keterbukaan dan partisipasi masyarakat seperti dikehendaki oleh Undang-Undang Keterbukaan Informasi Publik dan Undang-Undang Pelayanan Publik, Undang-Undang Nomor Pemerintahan Daerah pun menghendaki hal serupa, bahwa pemerintah daerah dalam menyelenggarakan pemerintahan 


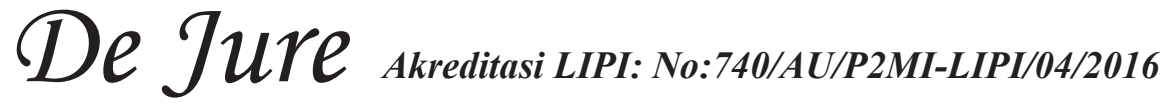

daerah haruslah mengacu kepada keterbukaan dan partisipasi masyarakat.

Berdasarkan temuan Direktorat Jenderal Otonomi Daerah dan keterangan dari Komisi Informasi ternyata masih banyak organisasi pemerintah daerah yang tidak menerapkan standar pelayanan dalam melaksanakan tugasnya. standar pelayanan yaitu tolok ukur yang dipergunakan sebagai pedoman penyelenggaraan pelayanan dan acuan penilaian kualitas pelayanan sebagai kewajiban dan janji penyelenggara kepada masyarakat dalam rangka pelayanan yang berkualitas, cepat, mudah, terjangkau dan terukur. Komponen standar pelayanan publik diatur dalam Pasal 21 Undang-Undang Nomor 25 Tahun 2009 Tentang Pelayanan Publik, sekurang-kurangnya meliputi:
a. dasar hukum;
b. persyaratan;
c. sistem, mekanisme, dan prosedur;
d. jangka waktu penyelesaian;
e. biaya/tarif;
f. produk pelayanan;
g. sarana, prasarana, dan/atau fasilitas;
h. kompetensi pelaksana;
i. pengawasan internal;
j. penanganan pengaduan, saran, dan masukan;
k. jumlah pelaksana;
1. jaminan pelayanan yang memberikan kepastian pelayanan dilaksanakan sesuai dengan standar pelayanan;
$m$ jaminan keamanan dan keselamatan pelayanan dalam bentuk komitmen untuk memberikan rasa aman, bebas dari bahaya, dan risiko keragu-raguan; dan
n. evaluasi kinerja pelaksana.

Informasi mengenai Standar Pelayanan ini pula yang seringkali tidak dipenuhi oleh badan publik. Dalam konteks pelayanan publik standar pelayanan adalah bagian dari sistem informasi yang harus dikelola oleh penyelenggara pelayanan publik sesuai dengan Pasal 23 Undang-Undang Nomor 25 Tahun 2009 Tentang Pelayanan Publik, menurut ketentuan tersebut penyelenggara pelayanan publik berkewajiban mengelola Sistem Informasi yang terdiri atas sistem informasi elektronik atau non-elektronik, sekurangkurangnya meliputi:

a. profil Penyelenggara;

b. profil Pelaksana;

c. standar pelayanan;

d. maklumat pelayanan;

e. pengelolaan pengaduan; dan

f. penilaian kinerja.

Pasal 23 Undang-Undang Pelayanan Publik pun menyatakan bahwa informasi tersebut di atas wajib disediakan kepada masyarakat secara terbuka dan mudah diakses. Hal ini sejalan dengan Undang-Undang Nomor 14 Tahun 2008 Tentang Keterbukaan Informasi Publik.

Ketidaksiapan organisasi pemerintah daerah dalam menyiapkan Standar Pelayanan ini belum juga teratasi, di mana hingga kini masih banyak organisasi pemerintah daerah yang tidak memiliki informasi standar pelayanan sehingga masyarakat tidak dapat mengakses pelayanan dengan baik. Padahal Standar Pelayanan ini sangat penting dalam melakukan evaluasi terhadap pelaksanaan programprogram organisasi pemerintahan daerah yang bersangkutan (http://www.beritakotamakassar. com/index.php?option=read\&newsid=57409). Selain itu, standar pelayanan juga diperlukan untuk menjawab isu-isu krusial dalam penyelenggaraan Pemerintahan Daerah, khususnya dalam penyediaan pelayanan dasar yang bermuara pada penciptaan kesejahteraan rakyat.

Untuk menyongsong sebuah masyarakat yang demokratis memerlukan dukungan perangkat hukum dan kontrol masyarakat terhadap penyelenggara negara. Salah satu cara memperkuat kontrol masyarakat itu adalah dengan adanya jaminan untuk memperoleh informasi. Dengan adanya transparansi dan keterbukaan informasi, penyalahgunaan kewenangan dan kekuasaan oleh pemerintah dapat dicegah, sehingga pada akhirnya akan tercipta pemerintahan yang bersih, transparan dan akuntabel.

Pemerintahan yang bersifat terbuka pun dapat meminimalkan terjadinya praktik korupsi, hal ini disebabkan, korupsi umumnya tumbuh dan berkembang pada rezim ketertutupan.

Terkait korelasi antara keterbukaan informasi dan pelayanan publik, Indonesia telah memiliki dua undang-undang baru yang mungkin dinanti sejak lama, karena melalui dua undang-undang 
inilah negara menegaskan pemenuhan hak asasi terhadap warga negaranya. Hak yang termuat dalam kedua undang-undang tersebut adalah hak asasi yang dijamin secara internasional, yang satu berkaitan dengan hak sosial-politik sedangkan yang satu lagi erat kaitannya dengan hak ekosob, meski dalam pemenuhannya keduanya tidak dapat dipisah-pisahkan secara tegas, keterkaitan antara hak sipol dan ekosob sesuai dengan kesepakatan bahwa hak asasi manusia harus diperhitungkan sebagai satu kesatuan yang menyeluruh (Smith dkk, 2008). Artinya, hak-hak sipil, politik, ekonomi, sosial dan budaya saling berkaitan (indivisible) dan saling membutuhkan (interdependence). Kedua undang-undang yang dimaksud adalah Undang-Undang Nomor 14 Tahun 2008 Tentang Keterbukaan Informasi Publik, dan Undang-Undang Nomor 25 Tahun 2009 Tentang Pelayanan Publik. Secara historis proses pembentukan kedua undang-undang ini berlangsung cukup lama, sejak pengajuan RUU hingga akhirnya disahkan menjadi undangundang.

Regulasi yang mengatur mengenai akses publik merupakan suatu hal yang positif dalam suatu negara demokrasi yang mengharapkan tercapainya pemerintah dan pengolahan badanbadan publik yang memiliki keterbukaan kepada publik, Pengertian Badan Publik menurut UU KIP adalah lembaga eksekutif, legislatif, yudikatif dan badan lain yang fungsi dan tugas pokoknya berkaitan dengan penyelenggaraan negara, yang sebagian atau seluruh dananya bersumber dari anggaran pendapatan dan belanja negara dan/ atau anggaran pendapatan belanja daerah, atau organisasi non pemerintah sepanjang sebagian atau seluruh dananya bersumber dari anggaran pendapatan dan belanja negara dan/atau anggaran pendapatan belanja daerah, sumbangan masyarakat dan/atau luar negeri.

Undang-Undang Keterbukaan Informasi Publik(UU KIP) memiliki keterkaitan dengan penyelenggaraan Pelayanan Publik, karena salah satu asas dalam penyelenggaraan pelayanan publik adalah asas keterbukaan.Selain itu ketentuan mengenai informasi dalam penyelenggaraan pelayanan publik pun diatur secara khusus pada Pasal 23 Undang-Undang Nomor 25 Tahun 2009 Tentang Pelayanan Publik. Juga karena penyelenggara pelayanan publik seperti dimaksud oleh Pasal 1 ayat (2) Undang-Undang Pelayanan
Publik adalah pihak yang termasuk dalam kategori badan publik menurut UU KIP sepanjang memenuhi unsur yang termuat dalam Pasal 1 ayat (3) Undang-Undang Keterbukaan Informasi Publik. Selain keterbukaan informasi itu sendiri, benang merah antara UU KIP dan UU Pelayanan Publik adalah upaya untuk meningkatkan peran serta dan partisipasi masyarakat dalam kebijakankebijakan publik. Dan Satriana pernah mengatakan bahwa sebenarnya UU KIP dan UU Pelayanan Publik itu dapat dikatakan satu paket peraturan perundang-undangan yang berupaya mendorong penyelenggaraaan pemerintahan yang lebih baik dan transparan. Dengan demikian penulis memandang bahwa keterbukaan informasi publik merupakan bagian penting dari penyelenggaraan pelayanan publik juga merupakan hak yang sangat penting dan strategis bagi warga negara untuk menuju akses terhadap hak-hak lainnya, karena bagaimana mungkin akan mendapatkan hak pendidikan, kesehatan, dan pelayanan lainnya dengan baik jika informasi yang diperoleh mengenai hak-hak tersebut tidaklah didapatkan secara tepat dan benar.

Buruknya kinerja pelayanan publik selama ini antara lain dikarenakan belum dilaksanakannya transparansi dalam penyelenggaraan pelayanan publik. Oleh karena itu, pelayanan publik harus dilaksanakan secara transparan oleh setiap unit pelayanan instansi pemerintah karena kualitas kinerja birokrasi pelayanan publik memiliki implikasi yang luas dalam mencapai kesejahteraan masyarakat. (http://fisip.untagjakarta.ac.id/ wpcontent/uploads/2010/07/PenyelenggaraanPelayananPublikdiIndonesia)

Keterbukaan (transparansi) erat kaitannya dengan partisipasi. Transparansi berarti terbukanya akses bagi seluruh masyarakat terhadap semua informasi yang terkait dengan seluruh kegiatan termasuk prosesnya, dengan adanya informasi yang terbuka maka akan memudahkan kontrol sosial dari masyarakat.

Secara umum, Undang-Undang KIP diharapkan akan membangun keterbukaan informasi di lembaga pemerintah dan non pemerintah yang selama ini dianggap sulit dijangkau oleh masyarakat. Secara khusus, eksistensi regulasi mengenai keterbukaan informasi publik dapat mendorong suatu masyarakat menjadi lebih demokratis dengan memungkinkan adanya akses masyarakat 


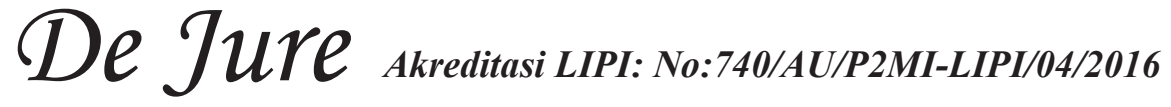

terhadap informasi yang dimiliki pemerintah baik pemerintah pusat, pemerintah daerah maupun lembaga-lembaga publik lain seperti lembaga pendidikan dan lembaga kesehatan, misalnya rumah sakit. Oleh sebab itu, Undang-Undang KIP mendukung keterbukaan informasi di seluruh lembaga pemerintah dan non pemerintah yang terlibat dengan penyelenggaraan pelayanan publik. Dilain pihak, satu hal yang memiliki korelasi erat dengan keterbukaan informasi adalah tentang pelayanan publik di negeri ini, salah satu masalah dalam penyelenggaraan pelayanan publik adalah tidak adanya keterbukaan dan transparansi mengenai informasi-informasi yang dibutuhkan oleh masyarakat.

Hak atas Informasi menjadi penting karena dengan terbukanya penyelenggaraan negara untuk diawasi publik, penyelenggaraan negara tersebut semakin dapat dipertanggungjawabkan. Hak setiap orang untuk memperoleh informasi juga relevan untuk meningkatkan kualitas pelayanan dan juga pelibatan masyarakat dalam proses pengambilan keputusan publik. Partisipasi atau pelibatan masyarakat tidak banyak berarti tanpa jaminan keterbukaan Informasi Publik. Dengan membuka akses publik terhadap informasi diharapkan badan publik termotivasi untuk bertanggung jawab dan berorientasi kepada pelayanan publik yang sebaik-baiknya. Dengan demikian, hal itu dapat mempercepat perwujudan pemerintahan yang terbuka yang merupakan upaya strategis mencegah praktik korupsi, kolusi, dan nepotisme $(\mathrm{KKN})$, dan terciptanya kepemerintahan yang baik (good governance).

Berlakunya UU KIP tentu sajaakan memberikan berbagai macam implikasi sebagaimana lazimnya suatu kebijakan terutama setingkat UU diterapkan di daerah. Apabila dilihat dalam konteks hubungan antara pemerintah daerah dengan warganegaranya, secara garis besar implikasi penerapan UU KIP tersebutmelekat pada dua pihak, yaitu penyelenggara pemerintahan daerah dan masyarakat atau publik. Pada pihak penyelenggara pemerintahan daerah, ada beberapa implikasi penerapan UU KIP, seperti kesiapan pemerintah daerah untuk menyediakan informasi publik seperti diatur oleh Pasal 9, 10, dan 11 UU KIP, yaitu informasi yang wajib disediakan dan diumumkan secara berkala, informasi yang wajib diumumkan serta merta, dan informasi yang wajib tersedia setiap saat. Namun dalam
UU KIP tidak hanya pemerintah daerah saja yang terkena kewajiban-kewajiban tersebut, namun juga organisasi pemerintah dan non pemerintah lain yang tugas pokoknya berkaitan dengan penyelenggaraan negara dan sebagian atau seluruh dananya bersumber dari anggaran pendapatan dan belanja negara dan/atau anggaran pendapatan belanja daerah, sumbangan masyarakat dan/atau luar negeri.

Implikasi lain bagi pemerintah daerah dengan diterapkannya UU KIP adalah masyarakat berhak mengetahui proses pengambilan suatu kebijakan publik termasuk dalam konteks pelayanan publik. Termasuk juga isi keputusan dan alasan pengambilan keputusan kebijakan publik serta informasi tentang kegiatan pelaksanaan kebijakan publik tersebut beserta hasil-hasilnya harus terbuka dan dapat diakses oleh publik. Oleh karena itu, ada konsekuensi bahwa aparatur pemerintahan atau badan publik harus bersedia secara terbuka dan jujur memberikan informasi yang dibutuhkan publik. Hal seperti ini bagi sebagian atau mungkin seluruhnya dari aparat pemerintah atau badan publik merupakan hal yang belum atau tidak terbiasa untuk dilakukan. Tetapi implikasi ini beserta konsekuensinya tetap harus dihadapi sejalan dengan penerapan UU KIP. Sehingga menjadi penting bagaimana pemerintah daerah mampu melaksanakan UU KIP ini, terutama dalam tugas-tugasnya yang berkaitan dengan penyelenggaraan pelayanan publik, karena pelayanan publik sangatlah erat kaitannya dengan kewajiban negara dan pemenuhan hak-hak warga negara (Puspitosari dkk, 2008).

Masih dalam konteks keterkaitan hak atas informasi dan hak atas pelayanan publik dalam persepektif HAM, Pelayanan publik termasuk ke dalam hak ekosob yang esensial dari HAM internasional. Hak ekosob bersamasama dengan hak-hak sipil dan politik menjadi bagian dari the international bill of human rights. Dengan demikian, hak ekosob tidak dapat ditempatkan di bawah hak-hak sipil dan politik. Hak ekosob mengubah kebutuhan menjadi hak, atas dasar keadilan dan martabat manusia. Hak ekosob memungkinkan masyarakat menjadikan kebutuhan pokok mereka sebagai sebuah hak yang harus diklaim (rights to claim) dan bukannya sumbangan yang didapat (charity to receive). Hakhak ekosob sering juga disebut sebagai hak-hak positif, karena tidak seperti dalam hak-hak sipil 
dan politik, dalam hak ekosob ini negara harus berperan atau mengambil langkah positif untuk menjamin terpenuhinya hak-hak ini.

Hak ekonomi, sosial dan budaya dikelompokkan sebagai hak asasi generasi kedua. Roy Gregory dan Philip Giddings membagi hak asasi manusia menjadi dua, yaitu: substantive rights (hak-hak substantif) dan procedural rights (hak-hak prosedural). Hak-hak substantif adalah hak-hak yang termasuk dalam hak-hak asasi manusia generasi pertama, yaitu hak-hak di bidang sipil dan politik, misalnya hak hidup, hak ikut serta dalam pemilihan umum, hak berserikat, berkumpul dan mengeluarkan pikiran, hak untuk tidak disiksa, dan lain-lain. Hak-hak lain yang termasuk dalam hak-hak substantif adalah hakhak asasi manusia generasi kedua, yaitu hak-hak ekonomi, sosial dan budaya, misalnya, hak-hak atas kesehatan, pendidikan, pekerjaan, dan lainlain. Hak-hak terakhir dari kategori hak-hak substantif adalah hak-hak generasi ketiga yang disebut juga sebagai hak-hak solidaritas, misalnya, hak atas lingkungan hidup yang sehat, hak atas pembangunan. (Allan R.Brewer, 2009)

Hak-hak kategori kedua adalah hak-hak prosedural. Gregory dan Giddings membagi hakhak kategori ini kedalam dua bagian, yaitu:

a. Hak atas administrasi yang baik (right togood administration), yaitu hak mendapatkan perlakuan yang sama, adil, dan wajar dari para pejabat publik dalam memenuhi hakhak substantif sebagaimana disebutkan di atas.

b. Hak menyampaikan keluhan atau keberatan (right to complain), hak untuk didengar (rightto be heard), dan mendapatkan ganti rugi apabila mengalami kerugian akibat tindakan pemerintah (right to have corrective action).

Berbicara Undang-Undang KIP dan UU Pelayanan Publik pun kita berbicara terkait hakhak prosedural sebagaimana dijelaskan oleh Gregory dan Giddings. Jenis hak prosedural yang kedua, yaitu the right to complain, to be heard and to have corrective action merupakan suatu hak yang penting terutama ketika masyarakat atau individu berhubungan dengan negara atau pemerintah. Masyarakat memiliki hak untuk 'memperkarakan' melalui impartial arbiter. Masyarakat harus merasa yakin bahwa kekuasaan publik dilaksanakan secara adil dan patut berdasarkan hukum dan keadilan, dan hal ini bermakna adanya hak untuk didengar secara adil di muka pemutus perkara serta hak untuk memiliki kesempatan yang adil (Mutaqien dkk,2010).

Hak-hak prosedural di atas merupakan salah satu ciri penting negara hukum yang demokratis, sebagaimana dikatakan oleh Bagir Manan, yaitu terdapatnya jaminan bagi setiap orang untuk 'memperkarakan' negara atau pemerintah yang melakukan atau dianggap melakukan tindakan yang merugikan, baik secara materil maupun imateril (Mutaqien dkk,2010). Bagir Manan mengatakan bahwa memperkarakan di sini diartikan dalam arti luas, mulai dari keluhan, keberatan, sampai pada tingkat menggugat secara hukum. Jaminan ini harus pula disertai dengan tersedianya lembaga serta mekanisme penyelesaian yang tidak memihak, walaupun yang dihadapi adalah negara atau pemerintah. Lembaga seperti Komisi Informasi menjadi bagian penting dalam hal ini.

Hak-hak prosedural merupakan salah satu indikator pemenuhan hak-hak substantif. Kegagalan pemenuhan hak-hak prosedural dapat dipandang sebagai kegagalan dalam melakukan pemenuhan hak-hak substantif. Dalam hal ini, dapat terlihat sebuah hubungan HAM yang erat dalam "Implementasi Undang-Undang KIP terhadap pelayanan publik", karena hak atas informasi merupakan hak sipil-politik sedangkan pelayanan publik termasuk ke dalam hak ekosob, dalam arti lain maka terdapat hak sipol dalam upaya pemenuhan hak ekosob.

Keterkaitan antarahak sipol dan ekosobsesuai dengan kesepakatan bahwa hak asasi manusia harus diperhitungkan sebagai satu kesatuan yang menyeluruh (Smith dkk, 2008). Artinya, hak-hak sipil, politik, ekonomi, sosial dan budaya saling berkaitan (indivisible) dan saling membutuhkan (interdependence), dan harus diterapkan secara adil baik terhadap individu maupun kelompok.

\section{KESIMPULAN}

Bahwa benang merah antara UU KIP dan UU Pelayanan Publik adalah upaya untuk meningkatkan peran serta dan partisipasi masyarakat dalam kebijakan-kebijakan publik.

Buruknya kinerja pelayanan publik selama ini antara lain dikarenakan belum dilaksanakannya 


\section{De JuTe akreditasi LIPI: No:740/AU/P2MI-LIPI/04/2016}

transparansi dalam penyelenggaraan pelayanan publik.

\section{SARAN}

Pelayanan publik harus dilaksanakan secara transparan oleh setiap unit pelayanan instansi pemerintah karena kualitas kinerja birokrasi pelayanan publik memiliki implikasi yang luas dalam mencapai kesejahteraan masyarakat. 


\section{DAFTAR KEPUSTAKAAN}

Allan R. Brewer-Car'Ias, (2009) Constitutional Protection Of Human Rights In Latin

Hesti Puspitosari, Khalikussabir, Luthfi Kurniawan, (2011) Filosofi Pelayanan Publik, Setara Press, Malang,

Jimly Asshiddiqie, (2005) Hukum Tata Negara dan Pilar-Pilar Demokrasi, Konstitusi Press, Jakarta,

MetteJkaer dan Klavs Kinnerup, (2003)" Good Governance: Bagaimana kaitannya dengan

HAM?", dalam buku Hak Asasi Manusia dan Good Governance, Pustaka HAM Raoul Wallenberg Institute, 2003,

Miriam Budiarjo, (1993), Dasar-Dasar Ilmu Politik. PT. Gramedia Pustaka Utama, Jakarta,

M Ryaas Rasjid, (1998) Desentralisasi Dalam Menunjang Pembangunan Daerah Dalam Pembangunan Administrasi di Indonesia, Pustaka LP3ES, Jakarta,

Sirajuddin, Didik Sukriono, (2011) Winardi, Hukum Pelayanan Publik berbasis partisipasi \&Keterbukaan Informasi, Setara Press, Malang,

Zulkarnain, Sirajuddin, dan Aan Eko Widiarto, (2006) Menggagas Keterbukaan Informasi

Publik: upaya kolektif berantas korupsi, Malang Corruption Watch dan YAPPIKA, Malang

\section{Makalah Seminar dan Hasil Penelitian}

Indra Perwira, (2009), Tanggung Jawab Negara Dalam Pemenuhan Hak

Atas Kesehatan Berdasarkan Undang-Undang 1945, disertasi, Universitas Padjadjaran, Bandung,

Puslitbang BPHN Kemenkumham RI, (2011) Seminar Tentang Pelayanan Publik dilaksanakan 11 Maret 2011 di Yogyakarta, laporan seminar BPHN, Jakarta

Puslitbang BPHN Kemenkumham RI (2013), Efektivitas Pembentukan Komisi Informasi di Daerah, Jakarta

Zainal Muttaqien, Dicky Risman, Susi Dwi Harijanti, (2010) "Implementasi Pelayanan
Publik di Bidang Pendidikan Tinggi Sebagai Upaya Pemenuhan Hak Asasi Manusia Prosedural di Universitas Padjadjaran", Laporan Akhir Penelitian Andalan Fakultas Hukum Universitas Padjadjaran, Bandung

\section{Internet}

http://www.ditjen-otda.depdagri.go.id/index.php/ categoryblog/70-makna-desentralisasi-itupelibatan-masyarakat

http://agusdarwis.wordpress.com/2010/08/09/ pelayanan-publik-keterbukaan-informasi/

http://digilib.its.ac.id/public/ITS-Undergraduate8118-1303100062-Bab1.pdf

http://www.beritakotamakassar.com/index. php?option=read\&newsid $=57409$

http://fisip.untagjakarta.ac.id/wpcontent/ uploads/2010/07/PenyelenggaraanPelayananPublikdiIndonesia

\section{Peraturan Perundang-Undangan}

Undang-Undang Dasar 1945

Undang-Undang Nomor 28 Tahun 1999 tentang Penyelenggara Negara yang Bersih dan Bebasdari Korupsi, Kolusi, dan Nepotisme.

Undang-Undang Nomor 14 Tahun 2008 Tentang Keterbukaan Informasi Publik

25 Tahun 2009 Tentang Pelayanan Publik 